\title{
Without Truth, No Reconciliation. The South African Rechtsstaat and the Apartheid Past ${ }^{1}$
}

\author{
By Gerhard Werle
}

\section{Introduction}

The new South Africa commits itself to respect of human rights and the rule of law in the preamble to its Constitution. The new Rechtsstaat is confronted with the heritage of the Apartheid past. On 28 June 1995, following a heated debate, the South African Parliament passed a law with the programmatic title "Promotion of National Unity and Reconciliation Act". ${ }^{2}$ The Act was the result of 130 hours of consultation in committee and over 300 amendments.

The law deals with familiar questions: How should the new order deal with the wrongs of the old? How can victims of human rights abuses be helped and their dignity restored? Should the criminality of the Apartheid system be punished, or is an amnesty called for in the interests of internal peace?

This article will analyse the South African answers to these questions. I need first to describe the past which South Africa has to face. I will deal, secondly, with the background to the South African Constitution of 1994. I will then concentrate on the Truth and Reconciliation Act itself.

\section{The Apartheid Past}

1948 is often called the year of the birth of Apartheid. It is the year in which the Afrikaans National Party took over the reigns of government. This Party itself named its policy of

This text is the English version of the writer's inaugural lecture, which was delivered on 18 May 1995 at the Law Faculty of the Humboldt University of Berlin. The text, which was originally based on the bill of 17 May 1995, has been reworked and footnotes have been added, but the form and style of the original lecture have been maintained. For her help in the preparation of this article, thanks to Cathy Powell, B.A., LL.B., LL.M.

2 Act 34 of 1995 (hereafter: Reconciliation Act). The Act was passed by the National Assembly on 28 June 1995 with amendments introduced by the Senate. 
systematic racial discrimination "Apartheid". ${ }^{3}$ The history of discrimination, however, reaches much further back. ${ }^{4}$ It starts with the seizure of land by Dutch settlers in the mid17th century. In 1910, after the Anglo-Boer war, the South African Union was created as a political unit. The Union saw itself as a white State and committed itself to racial separation. While there was a fair amount of discrimination country-wide, it was neither uniform nor systematic. That changed in 1948. From this date racism became state doctrine in South Africa. 5

Traditional racism was complemented by countless discriminatory laws. ${ }^{6}$ These laws were passed by a sovereign Parliament and had precedence over the rights recognised by the colour-blind Roman-Dutch common law. In this way the common law was overwritten by statutory discriminations and rendered almost powerless. Here are a few central characteristics of Apartheid legality:

- The basic rule is simple: The legal status of each human being follows on his/her racial classification. The criterion "race" is therefore defined in a readily-accessible bureaucratic manner. The South African legislature unified the hitherto different and varied definitions of racial classification. The Population Registration $\mathrm{Act}^{7}$ distinguished between Whites and - in the language of Apartheid - Coloureds - and Natives, that is, Blacks. The goal was the classification of the entire population, so that racial discrimination could be carried out smoothly.

- Discrimination covered all areas of public and private life. In the state of South Africa there were, therefore, different legal orders for different racial groups. There was white law and black law.

Cf. Speech of the then Senator Verwoerd on 3 September 1948 in the South African Senate, in: Pelzer, Verwoerd aan die Woord, 1963, 1-16. Verwoerd became Minister of Native Affairs in 1950 and Prime Minister in 1958.

Cf. Davenport, South Africa: A Modem History, 1991, 4th ed., 111-66; $201 \mathrm{ff}$; Bundy, in: Murray / O'Regan (eds.), No Place to Rest, 1990, 3-13.

5 This is a remarkable turn against the tide of world history. National socialist racism had just been overturned and the process of decolonialisation was in full swing. But in South Africa a system of racial discrimination was put into place; a system of state-legitimated human rights abuses.

6 Cf. for example the overview presented by Horrell, Laws affecting Race Relations in South Africa, 1978, 112-54; Sodemann, Die Gesetze der Apartheid, 1986.

7 Population Registration Act 30 of 1950. Countless amending acts followed to guide the extensive administrative machinery which was developed to carry out the categorisation. 
- Against these basic conditions it goes without saying that the franchise remained exclusively with the whites. The franchise which coloureds still retained in the Cape after 1910 was seen as a threat and soon removed. ${ }^{8}$

- An important goal was the racial zoning of the land into white and black territories. In this respect the groundwork had already been laid by the Land Act of 1913. ${ }^{9}$ This recognised the colonial acquisition of land in statutory form and juristically fenced the black population in: Blacks could hold land in only $7 \%$ of the country (later $13 \%$ ) in the so-called Native Reserves. The policy of geographical separation was then carried out systematically in the cities. The Group Areas Act of $1950^{10}$ created the necessary conditions for racial residential areas. Particularly affected were the Coloureds, who were, for example, forced out of the centre of Cape Town. Sophiatown near Johannesburg was flattened and became a white suburb. The name of the new, white suburb mocked the victims of the removal. It was called: "Triomf".

- The white areas were shielded off by a rigid residential permit system (influx control) which was meant to hinder the influx of blacks into the towns. ${ }^{11}$ Blacks had the right to live in the cities to the extent that, and only for as long as, their labour was required there. The hated "pass", which had to be carried on one's person at all times, played a role here. Millions of blacks were punished for contraventions of the pass laws. They experienced Law and Justice as an instrument of oppression in the hands of the white minority.

- The racist utopia of Apartheid was the creation of a white South Africa. The main means to this goal was the forcing of the black population into the already overpopulated homelands. Forced resettlement followed - the displacement of about 3,5 million people. ${ }^{12}$ The aim of the homeland policy was as simple as it was cruel: Denationalise as many black South Africans as possible, establish a ring of formally

The Separate Representation of Voters Act 45 of 1951 removed Coloureds from the common voters' roll in the Cape. This Act led to a lengthy clash of wills between the Supreme Court and Parliament, ending finally in a victory for the latter. Cf. Harris v. Minister of the Interior, 1952 (2) SA 428 (A), Minister of the Interior v. Harris, 1952 (4) SA 769 (A) and finally Collins $v$. Minister of the Interior, 1957 (1) SA 552 (A). Cf. also Boulle, in: Rycroft / Boulle / Robertson / Spiller (eds.), Race and the Law in South Africa, 1987, $14 \mathrm{ff}$.

Land Act 27 of 1913. Robertson summarises the Act in Rycroft et al. (fn. 8), 119; $112 \mathrm{ff}$.

Act 41 of 1950 . O'Regan, op. cit., $162 \mathrm{ff}$.

Cf. Murray / O'Regan (fn. 4) and Platzky / Walker, The Surplus People: Forced Removals in South Africa, 1985. 
independent black states and exploit the labour power of its black inhabitants as the need arises.

- Opportunities for black development were systematically restricted. In the field of labour law, for example, a colour bar was introduced, barring particular jobs to black workers. Black trade unions were outlawed. Within education, well-equipped white institutions were separated strictly from badly-equipped black institutions.

- There was even discrimination in the provision of public facilities. The legal basis for this so-called "Petty Apartheid" was provided by the Reservation of Separate Amenities Act $1953 .^{13}$ There was Apartheid in sports, in the churches, in hotels and restaurants, on the beaches and in parks, busses, trains, theatres and cinemas. There were absurdities such as "toilet" Apartheid and tragedies when people died because they had the wrong skin colour for the doctor. ${ }^{14}$

- There was also a South African version of the Nazi Blood Protection Act. An earlier Immorality Act had already banned extra-marital sexual intercourse between whites and blacks under threat of punishment in 1927. In 1949 a ban on marriages across the colour line followed and in 1950 sexual intercourse was also banned between whites and coloureds. ${ }^{15}$

The international community condemned this system as a crime against humanity. ${ }^{16}$ And Blacks within South Africa did not take their deteriorating position in racial politics lying down. Waves of resistance swelled up in each of the following decades. In the 1950's a civil disobedience campaign was carried out, based on Ghandi's example. After the Sharpeville massacre of 1960 - in which the police shot blindly into an unarmed mass - the liberation movements were banned and they resorted to armed struggle. The military resistance could be contained - momentarily. But the unrest continued. In 1976, the school uprisings of Soweto became a beacon for the fight against Apartheid. The resistance to the proposed constitutional reform of 1983 led to the formation of the United Democratic Front, which had close links to the ANC. The white government then started to grant concessions, but they were half-hearted and too late. From 1986 onwards South Africa was under a permanent state of emergency. The black townships became ungovernable. ${ }^{17}$

13

14

15

16

17

Act 49 of 1953.

Cf. Cápe Times of 27 January 1990 (!).

Immorality Act 5 of 1927; Prohibition of Mixed Marriages Act 55 of 1949; Immorality Act 23 of 1957.

Hinz, in: Sodemann (fn. 6), 192-193.

Cf. Davenport (fn. 4), $325 \mathrm{ff}$., especially at $332 \mathrm{ff}$., $356 \mathrm{ff}$., $389 \mathrm{ff}$., $437 \mathrm{ff}$. 
Against this background the importance of the repressive state apparatus for the survival of the system is obvious. An enormous body of security laws developed, which functioned by creating countless political crimes and drastic sentences. The first striking example is the Suppression of Communism Act of $1950 .{ }^{18}$ This was aimed not only at the members of the Communist Party (banned by the same Act) but also at anybody who stood for, defended or promoted a communist goal. As a result, all efforts directed against the system were branded as communist. This also covered, for example, the efforts of a priest to get the pass laws scrapped. The Act covered anyone and everyone who fought for human rights and a universal vote.

The most effective development was the unleashing of the power of the police. Criminal prosecution requires a public hearing and this implied possible loss of face and defeat for the government. It became a nuisance for the government merely to rely on repressive criminal laws and criminal procedure. So, from the beginning of the 1960's, the executive was given wide powers to detain without judicial scrutiny. ${ }^{19}$ What was done with the discretion thus enjoyed by the police still distresses the South African public today. People disappeared and were later found dead somewhere. In police custody people were injured, tortured and killed. Judicial scrutiny of such cases was usually blocked because the courts were cut off from the necessary information. And when the information was brought to court, judicial proceedings of ten ended such as in Steve Biko's case:

Steve Biko was the leader of a black students' movement. He was detained in 1977 and died 26 days later. The Minister of Justice, Krüger, announced that Steve Biko had died as a result of his hunger strike and added: "His death leaves me cold." Cynical National Party members congratulated the Minister for allowing Biko his democratic right to a hunger strike all the way to his death. An autopsy followed which established severe head injuries as the cause of death. At this point the police officer who had been responsible for Biko suddenly explained that Biko had hit his head against the wall after being confronted with evidence of his crimes. The police of ficer reported that Biko had then - unfortunately died while being transported in the back of a Land Rover, naked, to a military hospital 1000 kilometers away. The magistrate in charge of the autopsy stated tersely: "The available evidence does not prove that the death was brought about by any act of omission involving or amounting to an offence on the part of any person."

Act 44 of 1950 .

19 Cf. for example, s. 17 of the General Law Amendment Act 37 of 1963 (the 90-Day Clause); s. 7 of the Criminal Procedure Amendment Act 96 of 1965 and the culmination of previous police powers in the Internal Security Act 74 of 1982. A good summary is provided in Foster, Detention and Torture in South Africa, 1987.

There is an excellent description of the Biko incident in the Reader's Digest Illustrated History of South Africa, 1992, 2nd ed., 447, 449. 


\section{The Constitutional Provisions for the Legal Reckoning with the Apartheid Past}

Against such an historical background, it was a miracle to many: Despite the deep divisions, the ever-resurfacing violence, despite the enmity and hatred, South Africa has achieved a free and general election almost completely peacefully.

The transitional constitution of 1994 presents an historic compromise between the last government of the old order and the liberation movement. This compromise places limits on the extent to which the past can be processed. A general prosecution of Apartheid criminals and representatives of the old order was therefore not possible. A South African Nuremburg, which some people had demanded, is not reconcilable with the character of the transitional arrangement. The legality of Apartheid within its own system excludes the possibility of punishment, even though this legality offends human rights. And, despite its revolutionary nature, the transitional constitution relies on external continuity in the administration, police, justice and the military. ${ }^{21}$ There has been no testing of public of ficials and no purges. The administrators of the old order are therefore responsible for the development of democracy and a culture of human rights.

The above sets out the conditions confining South Africa in its dealing with the past. South Africa's first step was the Restitution of Land Rights Act. ${ }^{22}$ At issue here is the restitution of land rights lost through racist confiscation carried out in terms of the resettlement policy of the time. The Act covers the confiscation of land all the way back to 1913 and includes personal rights as well as real rights. The criteria for restitution are set out in the Constitution of 1994. The deciding factor is whether the measures under which the property was confiscated conflicts with the ban on racial discrimination in terms of s. 8 (2) of the Constitution. The Restitution of Land Rights Act provides for restitution, the provision of alternative land and compensation; it has established a specialised Land Claims Court as well as a Land Commission, which is to mediate claims.

The second important contribution to the processing of the Apartheid past comes in the form of the Promotion of National Unity and Reconciliation Act. This Act refers back to the "National Unity and Reconciliation" provision in the South African Constitution. This clause specially stresses the goal of national unity and proclaims national reconciliation to be its essential prerequisite. It aims at overcoming the past, with its division and conflict.

21

Continuity is the leading idea in the transitional provisions in Chapter 15 of the South African Interim Constitution (Constitution of the Republic of South Africa, Act 200 of 1993). See in particular ss. 229 ("Continuation of Existing Laws"), 235, 236, 241 (The Judiciary). In this regard cf. Corder, Towards a South African Constitution, 1994, 54 Modern Law Review, 491. 
The National Unity and Reconciliation provision describes the basic principles which will determine how South Africa reckons with the heritage of Apartheid: understanding instead of vengeance, reparation instead of retaliation, humanity (ubuntu) instead of victimisation this is how South Africa is meant to deal with its past. Within this context the legislature is given the task of drawing up the Amnesty Act. The relevant provision runs as follows:

"In order to advance ... reconciliation and reconstruction, amnesty shall be granted in respect of acts, omissions and offences associated with political objectives and committed in the course of the conflicts of the past. To this end, Parliament under this Constitution shall adopt a law determining the cut-off date, which shall be a date after 8 October 1990 and before 6 December 1993, and providing for the mechanisms, criteria and procedures, including tribunals, if any, through which such amnesty shall be dealt with at any time after the law has been passed." 23

This provision, formulated at the eleventh hour of the constitutional negotiations, leaves much to interpretation. As a result, a wide public debate followed soon afterwards on the ambit of the constitutional ruling. On the one hand, it was suggested that the Constitution provided the right to claim amnesty and that it denotes a clear and wide-reaching decision to let the past rest for the sake of reconciliation. "Grant amnesty, let the past rest, look forward!" would be a fair summary of this position. But there was also a broad spectrum of opinion against forgetting and simply cutting off the past. In terms of this approach the Constitution allows the Legislature a wide discretion in its drawing up of the Act, and this discretion must be used. This approach sees amnesty as merely a part of the essential public reckoning with the Apartheid past. And so people demanded a Commission for Truth and Reconciliation, referring to the Chilean experience: Only the public recognition of the truth levels the way to reconciliation and peace. ${ }^{24}$

\section{The Promotion of National Unity and Reconciliation Act}

The second position triumphed. The Reconciliation Act reaches far beyond the provisions for the regulation of the amnesty question. It decides for the thorough investigation of serious violations of human rights and stresses at the same time the necessity for compensation. It provides for the establishment of a Commission for Truth and Reconciliation, the tasks of which can be discerned from its structure. The Commission is divided into

Fifth paragraph of the National Unity and Reconciliation provision.

On the South African debate see in particular the contributions to two conferences held by IDASA and Justice in Transition, published as Boraine / Levy / Scheffer (eds.), Dealing with the Past: Truth and Reconciliation in South Africa, 1994; Boraine / Levy (eds.), The Healing of a Nation?, 1995. Reports on the Chilean experience were provided by former Chilean President Patricio Aylwin and a former member of the Chilean Commission for Truth and Reconciliation, José Zalaquett. 
three committees with specific mandates: first, there is a Human Rights Committee, which is to investigate serious abuses of human rights; second, an Amnesty Committee and third, a Committee for Compensation and Rehabilitation. ${ }^{25}$ The central theme of the investigation is serious human rights abuses, relating to the conflict of the past, inside and outside of South Africa. Serious rights abuses are, under the definition of the Act, killing, abduction, torture and severe ill-treatment. Government officials as well as members of the liberation movements are included. The committee is to find out the nature, causes and extent of such human rights abuses, the antecedents, the surrounding circumstances and the motives of those involved. The committee has, in particular, to find out the identity of those responsible. $^{26}$ The Amnesty Committee also has an important contribution to make to this clarification process. I will still deal with this in detail.

Beside its emphasis on investigation, the Act also stresses the position of the victims. The victims - and this category also includes dependants of the actual victims - are given the chance to tell the Commission their stories. A central part of the Reconciliation Act is the public recognition of the suffering of the victims. This recognition is seen as a prerequisite to the restoration of the victims' identity and dignity. Beside the moral restitution there is also to be material restitution, and the Commission is mandated to. present proposals in this regard. $^{27}$

The work of the Commission is limited by time requirements in two respects. The Reconciliation Act sets boundaries to the "past conflicts" themselves by restricting the subject matter of the Commission's work to a specific time frame. It begins on 1 March 1960, the month of the massacre at Sharpeville, and ends at the latest date possible under the Constitution. This is 5 December $1993 .^{28}$ A second time provision limits the period of work of the Commission to two years. ${ }^{29}$ The main idea here is to drive the painful investigation forward

Sections $12 \mathrm{ff}$., $16 \mathrm{ff}$. and $23 \mathrm{ff}$. of the Act. The duties of the Commission are described by the Minister of Justice, Dullah Omar, in Boraine / Levy (fn. 24), 2 ff., and Rwelamira in Rwelamira / Werle (fn. 22).

Sections 1 (1) (ix), 3 (1) and (4) (a).

For the details cf. ss. $23 \mathrm{ff}$.

This cut-off date for possible amnesty met with hefty resistance from the right-wing Freedom Front. In the run-up to the first free election of 1994 and on the first day of voting the rightwingers committed serious acts of violence, including bombing the airport of Johannesburg. The Freedom front, therefore, now demands as it did before - by way of an amendment to the Constitution - that the cut-off date for the granting of amnesty be extended to 10 May 1994, the day Mandela took up office as president. Cf. Fifth paragraph of the National Unity and Reconciliation provision.

Section 43 (1). The Commission's Report is to be tabled before the President within three months of closure of investigation (s. 43 (2)). 
as concentratedly and quickly as possible, so that the emphasis can then be on the process of healing.

The Commission's mandate shows what an enormous - yes, perhaps impossible - achievement is expected from the Truth Commission. It is meant to be some kind of "conscience of the nation", which should establish and protect the past. The Commission should contribute towards building a common memory for all South Africans. Here one hopes to make a new start possible for victims, for perpetrators and for society itself; to open the way to reconciliation and national unity.

How is such a demanding job carried out in practise? It is of primary importance that the Commission strive at political neutrality and objectivity. The Commission is envisaged as an independent legal person, which works apart from and without reference to other bodies. It has its own budget, its own staff and its own offices. The most heated question was, of course, how the members of the Commission - to number between 11 and 17 - are to be appointed. They will not be elected by Parliament or a parliamentary committee. There was the fear that this would lead to party-politicising and, therefore, a paralysing of the Commission's work. Instead, the President came to the fore, even more strongly than in the staffing of the Constitutional Court: President Mandela nominates the members of the Commission in consultation with the cabinet. He appoints the chairperson and deputy chairperson himself. All but two of the Commission members must be South African citizens. They must be impartial and respected. In addition, the Reconciliation Act requires that the members do not have a "high political profile", ${ }^{30}$ that is, they may not have stood for a particular political direction and been identified with it.

The Commission has no power to institute criminal proceedings and it is - as Minister of Justice Dullah Omar has often stressed - not a court. But it would be unable to carry out its mandate without powers similar to those of a court. The capacities of the Commission, therefore, include subpoena, questioning of witnesses and examining under oath, as well as search and seizure. An Investigating Unit is to carry out the investigatory function of the Commission and its committees, and it holds the relevant powers. The investigatory process is confidential and similar to the criminal procedural investigation, in particular as far as the provisions protecting witnesses and the right to a fair hearing are concerned. ${ }^{31}$

There are few provisions setting out the second stage in the procedure - the hearing itself. The Act recognises the right to legal representation for all defendants or otherwise interested persons; if necessary state legal representation will be provided by the Commission. 
There are also various provisions for the protection of witnesses. This is essential in view of the inflammatory nature of much of the evidence. ${ }^{32}$ Whether the hearings would be open to the public was a highly controversial question. ${ }^{33}$ Within the Government of National Unity the decision was first reached that the public would be excluded. The public was to have been informed only through announcements and reports from the Commission. This position, as contained in earlier drafts of the Act, led to a storm of protest, particularly from human rights organisations. People rightly feared that the success of the Commission was jeopardised through the exclusion of the public. The Truth Commission rests on the basic principle that the public recognition of the truth is essential for reconciliation. What is dealt with in the Truth Commission therefore involves all South Africans. But how can a common memory be created when the issues are dealt with behind closed doors and the public receives only filtered information? There are, of course, many interest groups in South Africa which would have preferred more discretion. Not the least of these are the representatives and functionaries of the old order. And so many of these repeated earlier criticism - that the whole process was one of "revenge of the victors" or a "witchhunt". Some pleaded that South Africa, for the sake of inner peace, should at least not deal with the past publically. Luckily, the South African Parliament did not capitulate to these special interests and decided for open hearings. Admittedly, there are to be exceptions - as happens in court. The Commission has the discretion to exclude the public or parts of it in the interests of revealing the truth or where people are endangered. Where a part of the public is excluded the victims in particular can be allowed access to the hearings. ${ }^{34}$

\section{The Question of Amnesty}

One of the thorniest issues in the Reconciliation Act is that of amnesty. The South African provision is a new creation, which has no parallel in the provisions of other societies in transition. Under German law, amnesty denotes the constitutive statutory setting out of prerequisites for an uncertain number of cases. ${ }^{35}$ If the requirements are met, further criminal proceedings are blocked. The Reconciliation Act does not set out such a constitutive provision. Although it determines material requirements for amnesty, it does not itself free those who meet the requirements from punishment. Whoever wants amnesty has to undergo a hearing before the Amnesty Committee and has to apply for the proceeding

Cf. ss. $34-35$.

Cf. s. 33.

Section 33 (1) (b) (ii).

For the justification for and limits of amnesty cf. Marxen, Rechtliche Grenzen der Amnestie, 1984. 
personally. ${ }^{36}$ The Amnesty Committee decides on the application independently and without having to answer to anybody, including the Commission. This independence, by the way, distinguishes the amnesty committee from the other committees, which work under the leadership of the Commission and have to answer to it.

The Amnesty Committee has enormous power: It decides in the first and last resort, because its decisions cannot be challenged. The effect of its decisions are highly unusual. Amnesty in the South African sense excludes not only criminal liability but also civil claims - and that regarding not only the person responsible but also the organisation behind him or the State. ${ }^{37}$ The exclusion of claims of damages is an act of charity for the responsible persons, but can affect the victims severely. The harshness of the provision is tempered only by the fact that cases relevant to damages issues are passed on to the Compensation Committee. Nonetheless, it is a particularly tricky part of the Reconciliation Act and it remains to be seen how the South African Constitutional Court will deal with the issue.

There is no appeal from cases decided by the Amnesty Committee, but the Committee is nonetheless obliged to follow certain criteria. The Constitution and the Reconciliation Act deal with what kind of cases can lead to amnesty. As already mentioned, the deciding factor in the Constitution is whether the acts were "associated" with political objectives and stand in connection with the conflicts of the past. The Reconciliation Act takes an enormous amount of effort to elaborate on these elements in three subsections with 15 further subdivisions. ${ }^{38}$ It first sets out the circle of persons for whom the granting of amnesty is a possibility. This is limited to officials of state bodies on the one hand, including those of the earlier homelands, and members and supporters of political organisations and liberation movements on the other hand. This covers not only the incidents between the state and the organisations which opposed it - say, for example, the security forces and the military wing of a liberation movement - but also incidents between the political organisations themselves. Those who carried out the acts must have become involved either in fulfillment of their offices or to further the political struggle. In other words, people who took part in the violent conflict of the past, in connection with an organisation, are covered. ${ }^{39}$

Secondly, the same provision deals with the objective "association" of act and political goal. The Act does without a conclusive definition. Instead, it provides guidelines which

36

37

38

39

Section $18(1)$.

Section 20 (7) (a).

Section 20 (2)-(4).

Acts which were politically motivated but not connected to a political organisation are hereby excluded from amnesty. This is questionable from the point of view of equality and justice but cannot be dealt with further here. 
draw in both objective and subjective considerations. These guidelines ${ }^{40}$ follow the socalled Norgaard Principles, which were drawn up by Carl Norgaard, the President of the European Human Rights Commission in connection with the transfer of power in Namibia. Norgaard concretised the concept of a "political crime" with reference to the principles of extradition. ${ }^{41}$ The Act therefore sets out the following considerations in establishing political "association":

- the motive of the person who committed the act;

- the context of the act;

- the legal and factual nature of the act, including its gravity;

- the target of the act - in particular, whether it was directed against private or public institutions, private individuals or political opponents;

- the ordering or approval of the act by the state or a political body;

- proportionality between the act and its goal. $^{42}$

Whether the proportionality between act and goal should also be a criterion was highly controversial in the consultations leading to the Reconciliation Act. Here I find it selfevident that the closeness between act and political goal is an important indication of whether the two are associated with each other. The critical point is, however, that it is possible to deny the "association" of act and political goal despite the presence of a political goal. The random shooting of civilians, such as in the St. James' church in Cape Town in 1993, may perhaps have been aimed towards forcing political opponents to compromise through terror. But in such cases the connection between the act and the political goal can be too loose for one to speak of "association".

The amnesty committee will quite clearly be faced with very difficult decisions as far as these issues are concerned. But at least the nature and direction of the criteria are clear in $\mathrm{s}$. 20 (3) of the Act. However, the very next subsection of the same provision seems to fudge the issue again. In terms of this ruling, amnesty should be decided in terms of the criteria of the now repealed Amnesty Act 151 of 1992. This Act, however, dealt only with political motivation and did not envisage the issue of proportionality at all. In this way the former President De Klerk granted amnesty in cases which would now be turned down as irreconcilable with the principle of proportionality. The members of the liberation movement also benefited from this approach and the National Party rejected the proportionality principle with this in mind. The claim is that, now that the punishment of members of the old government comes into play, stricter criteria are suddenly being used. The controversy

40

41

Section 20 (3).

42

Cf. the extracts in Boraine / Levy (fn. 24), $156 \mathrm{ff}$.

Section 20 (3) ( $f$ ) reads: "The relationship between the act, omission or offence and the political objective pursued, and in particular the directness and proximity of the relationship and the proportionality of the act, omission or offence to the objective pursued". 
ended in a compromise: The earlier Act was brought in as another guideline beside the guidelines already listed above. In other words, the same provision now states: "Have regard to the principle of proportionality!" and "It need not necessarily be proportional". The reference to the earlier Amnesty Act introduces an almost uncontrolled discretion. Nonetheless, these provisions could make sense if one sees the wider criterion as a function of the presidential right of pardon, which can come into play only exceptionally over and above the stricter guidelines. If the committee is clothed with the presidential right of pardon as well, its power increases considerably and its active role in the process of reconciliation is stressed.

The South African amnesty provision is as an entirely new provision regarding the following three aspects: Whoever wants amnesty must become actively involved and must do so within twelve months ${ }^{43}$ of the setting-up of the Commission, because then the time limit for applications expires. But the duty of co-operation of the person desiring amnesty reaches far beyond timeous application. "Full disclosure of all relevant facts" - this is the third requirement beside the application and the political nature of the crime. ${ }^{44}$ Amnesty is granted only to those who disclose all the relevant circumstances of their acts to the Commission. The applicant must, in other words, deliver a full confession. In this way the Reconciliation Act reveals the relationship between truth to reconciliation at its most sensitive: Those who have carried out the deeds must themselves disclose what they have done and, through their involvement in the hearing, recognise its wrongfulness. In this way they contribute what they can to the process of reconciliation.

Amnesty comes into question only when a crime is established in the individual case or with the co-operation of the perpetrator. The crime is condemned legally and publicly: The report is published and the parties named. ${ }^{45}$ Amnesty is therefore a two-stage process: In the first stage criminal liability is established, and, in the second, amnesty is granted. The Reconciliation Act thereby takes on the state's duty to investigate the criminality of the system: The investigation is carried out either in the amnesty hearing itself, or in the course of a criminal trial, where the amnesty application has not been made or is unsuccessful.

Without disclosure there is no amnesty. In the context of a system in transition this connection between amnesty and disclosure is innovative. Under South African conditions it is a solution which is both politically intelligent and legally workable. The requirement of full disclosure of all relevant facts is admittedly problematic. The first critical point is the possibility in terms of the Act that amnesty could be refused despite disclosure. Here the

43

44

45

Section 20 (6); but see also s. 37. 
Act itself offers a possible solution: A criminal-procedural protection for the applicant under which that evidence is inadmissible. ${ }^{46}$ A second possible objection to the provision that those concerned are indirectly forced to incriminate themselves - does not withstand analysis either. Those who do not wish to make disclosure before the Amnesty Committee do not suffer any legal disadvantages as a result. Having to live with the risk of criminal proceedings is the lot of every offender; should such a risk materialise, the accused who has not applied for amnesty has all the normal criminal-procedural safeguards at his or her disposal. ${ }^{47}$ And finally, offering amnesty as a quid pro quo to confession is acceptable. Criminal procedural law already recognises co-operation through confession in mitigation of sentence. The discretion to grant such rewards should be greater, not smaller, following a change of system. Particularly, where the crime of an entire system is concerned, the establishment of the historical truth makes a central contribution to reconciliation. The disclosure of the crimes by the criminals themselves reduces the need for punishment, which is then legitimated by the legislative decision for amnesty.

South Africa has developed a new model for dealing with state criminality. It has chosen a path between the extremes of heedless prosecution and blind amnesty. "Amnesty: yes. Forgetting: no." In South Africa's case this is no mere lip-service, but a concrete programme, which has been legally realised in the Reconciliation Act.

\section{Punishment is negotiable - the Truth is not}

It goes without saying that the Truth and Reconciliation Act cannot satisfy all demands and interests of a still divided society. The Reconciliation Act is, like the South African transition itself, the result of a compromise. The South Africans are going to have to learn to live with this compromise as well. Whether the goal of inner unity and reconciliation is reached depends not only on the work of the Commission, but also on the South Africans' content to reconcile - particularly the will of the victims. And that is a factor that cannot be governed by law. The Truth and Reconciliation Act, does, however, present a viable legal basis. A clear basic concept has emerged in difficult negotiations.

To summarise this basic concept:

- Inner unity requires reconciliation and this in turn requires the public recognition of the historical truth.

Thus nobody is forced to open his/herself to "public self-criticism, acknowledgement of guilt or displays of remorse". The critique of Quaritsch in connection with the so-called "Discussion Tribunals" proposed for Germany therefore does not hold. Cf. Quaritsch, in: Der Staat, Vol 31, 1992. 
- Those who are meant to forgive must know what they are forgiving. It is therefore insufficient to establish the historical truth in merely an abstract manner. Instead, the violence of the past and its causes must be named, the suffering of the victims concretely established.

- Truth has precedence over punishment, but also over amnesty. Acknowledgement legitimises amnesty, silence excludes it.

Punishment can, to a certain extent, be negotiated. The truth cannot. This is South Africa's message to societies in transition: There is no reconciliation without the truth. 
basic question is: Why is there so little benefit to be seen since the establishment of this agency:

This article addresses the following issues:

- the environmental situation in China,

- the basic principles of the Chinese environmental law and administration system,

- enforcement problems,

- future policy plans such as incorporating market mechanisms into environmental protection.

The article comes to the conclusion that the key to the future of the environment in China lies in the relationship between economic progress, national security and environmental protection.

\section{Without Truth, No Reconciliation}

\section{By Gerhard Werle}

In June 1995 South Africa passed the Promotion of National Unity and Reconciliation Act. This was South Africa's answer to the problems faced by societies in transition - how shall a new, democratic order deal with the wrongs of its non-democratic past?

The Promotion of National Unity and Reconciliation Act entrusts important prerequisites of reckoning with the past to a Truth and Reconciliation Commission. It divides the Commission into three committees: a Human Rights Committee, an Amnesty Committee and a Committee on Reparation and Rehabilitation. The Human Rights Committee is mandated to investigate serious human rights abuses committed in the course of the conflicts of the past, both by the government and by the liberation movements. It is the task of the Committee to establish the nature, extent and cause of the abuse; its history, the surrounding circumstances and the motives of those involved and the identity of those responsible. Through the Committee on Reparation and Rehabilitation, the Commission is to advise Parliament on the best means of rehabilitating the victims of human rights abuses morally and, to some extent, economically.

The Amnesty Committee deals with one of the most controversial issues in times of transition: whether to punish human rights offenders or grant amnesty for the sake of peace. Here South Africa has adopted a completely new solution by requiring those who need amnesty to apply of it and disclose all relevant facts with their application. In this way the perpetrators themselves contribute to reconciliation by acknowledging the wrongfulness of what they have done and assisting in the investigation. 